\title{
Biodegradation of polycyclic aromatic hydrocarbon by a halotolerant bacterial consortium isolated from marine environment
}

\author{
${ }^{1}$ *P. Arulazhagan; ${ }^{2}$ N. Vasudevan; ${ }^{3}$ I. T. Yeom \\ ${ }^{1,3}$ Department of Civil and Environmental Engineering, Sung Kyun Kwan University, 300 CheonCheon-Dong, Jangan- \\ Gu, Suwon, Gyeonggi-Do, South Korea \\ ${ }^{2}$ Centre for Environmental Studies, Anna University, Chennai - 600 025, India
}

Received 13 May 2010; ～revised 21 June 2010; accepted 18 July 2010; available online 1 September 2010

\begin{abstract}
The biodegradability of polycyclic aromatic hydrocarbons such as naphthalene, fluorene, anthracene and phenanthrene by a halotolerant bacterial consortium isolated from marine environment was investigated. The polycyclic aromatic hydrocarbons degrading bacterial consortium was enriched from mixture saline water samples collected from Chennai (Port of Chennai, salt pan), India. The consortium potently degraded polycyclic aromatic hydrocarbons (> 95\%) at 30g/L of sodium chloride concentration in 4 days. The consortium was able to degrade 39 to $45 \%$ of different polycyclic hydrocarbons at $60 \mathrm{~g} / \mathrm{L} \mathrm{NaCl}$ concentration. Due to increase in salinity, the percent degradation decreased. To enhance polycyclic aromatic hydrocarbons degradation, yeast extract was added as an additional substrate at $60 \mathrm{~g} / \mathrm{L} \mathrm{NaCl}$ concentration. After the addition of yeast extract, the consortium degraded $>74 \%$ of polycyclic aromatic hydrocarbons at $60 \mathrm{~g} / \mathrm{L} \mathrm{NaCl}$ concentration in 4 days. The consortium was also able to degrade PAHs at different concentrations (5, 10, 20, 50 and $100 \mathrm{ppm}$ ) with $30 \mathrm{~g} / \mathrm{L}$ of $\mathrm{NaCl}$ concentration. The polycyclic aromatic hydrocarbons degrading halotolerant bacterial consortium consists of three bacterial strains, namely Ochrobactrum sp., Enterobacter cloacae and Stenotrophomonas maltophilia.
\end{abstract}

Keywords:Biodegradation; Polycyclic aromatic hydrocarbons; Salinity; Halotolerant; Bacterial consortium

\section{INTRODUCTION}

Polycyclic aromatic hydrocarbons (PAHs) are ubiquitous environmental pollutants generated from both natural and anthropogenic processes and pose a serious concern to the health of aquatic life and humans through bioaccumulation (Hughes et al., 1997; Okafor and Opuene, 2007; Fagbote and Olaufekum, 2010; Lee and Byeon, 2010). PAHs are hydrophobic and readily adsorbed onto particulate matter and thus, coastal and marine sediments become the ultimate sinks for such compounds (Hughes et al., 1997; Yu et al., 2005; Osuji and Ezeburio, 2006). PAHs cause major impacts owing to their carcinogenic nature in marine organisms such as benthic, demersal and pelagic fishes, crustaceans and shellfish (Peruguni et al., 2007). The fate of PAHs in the environment is associated with both abiotic and biotic processes, including volatilization, photooxidation, chemical oxidation, bioaccumulation and microbial

\*Corresponding Author Email: arulazhagan_p@yahoo.co.in Tel.: +8231299 6699; Fax: +8231 2996693 transformation. Microbial activity has been deemed the most influential and significant cause of PAH removal (Cerniglia, 1993; Nwuche and Ugoji, 2008; Haghighat et al., 2008; Agbozu and Opuene, 2009; Atlas and Bragg, 2009). Considerable attention has focused on the metabolic pathways and genetics of degradation of low molecular mass PAHs, such as naphthalene, phenanthrene and anthracene, by gramnegative bacteria (Williams and Sayers, 1994). Hydrocarbon-degrading microorganisms usually exist in very low abundance in marine environments. Pollution by petroleum hydrocarbons, however, may stimulate the growth of such organisms and cause changes in the structure of microbial communities in the contaminated area. Identification of the key organisms that play roles in pollutant biodegradation is important for understanding, evaluating and developing in situ bioremediation strategies (Harayama et al., 2004). The ability of halophiles/ halotolerants to oxidize hydrocarbons in the presence 
of $\mathrm{NaCl}$ is useful for the biological treatment of saline ecosystems contaminated with petroleum products (Margesin and Schinner 2001; Mohanan et al., 2007). The rate of degradation of PAHs is mainly influenced by environmental limiting factors (salinity, nutrients, $\mathrm{pH}$, temperature, oxygen) and therefore may not be due to the enzymatic capacities of the indigenous hydrocarbon degrading bacterial strains (Atlas, 1981). Due to lack of nutrients in saline conditions, the consortium was not able to successfully grow and degrade the PAHs. As a result of nutrient deficiency, the bacterial consortium was unable to develop complete biosynthetic pathways and have complex nutrient requirements at high saline condition. The present article deals with the degradation of low molecular weight PAHs by a halotolerant bacterial consortium under saline conditions. In the natural environment, the sea water salinity was approximately $35 \mathrm{~g} / \mathrm{L}$ based on it the saline concentration of $30 \mathrm{~g} / \mathrm{L}$ was used in the present study. In order to check the salt tolerance and biodegradation of PAHs, the bacterial consortium was studied at $60 \mathrm{~g} / \mathrm{L}$ of $\mathrm{NaCl}$ concentration. The addition of yeast extract and its subsequent influence as a nutrient in this study has demonstrated that critical limiting factors such as salinity $(60 \mathrm{~g} / \mathrm{L}$ of $\mathrm{NaCl}$ concentration $)$ and nutrient requirements can be overcome. The research work was conducted between June 2007 and December 2009 at the Centre for Environmental Studies, Anna University Chennai, India.

\section{MATERIALS AND METHODS}

\section{Chemicals -PAHs}

In the present study, PAHs such as naphthalene, fluorene, anthracene and phenanthrene were purchased from Sigma-Aldrich, USA (purity $99 \%$ ). Anthracene was purchased from Merck, India (purity $98 \%$ ).

\section{Sample collection}

The bacterial consortium was isolated from a mixture of seven different sampling sites which included petroleum and coal contaminated sites, salt pans and the sea-port of Chennai, India.

\section{Mineral salts medium}

The carbon free mineral salts medium (MSM) contained $\mathrm{NH}_{4} \mathrm{Cl}-2.5 \mathrm{~g}, \mathrm{KH}_{2} \mathrm{PO}_{4}-5.46 \mathrm{~g}, \mathrm{Na}_{2} \mathrm{HPO}_{4}-4.76$ g, $\mathrm{MgSO}_{4}-0.20 \mathrm{~g}, \mathrm{NaCl}-30.0 \mathrm{~g}$ and Distilled water-1L at $\mathrm{pH}-7.4 \pm 0.2$. The final $\mathrm{pH}$ of the medium was adjusted to 7.4 with $0.1 \mathrm{~N} \mathrm{NaOH}$, and the medium was autoclaved $\left(121^{\circ} \mathrm{C}\right.$ for $\left.15 \mathrm{~min}\right)$ prior to the addition of PAHs. Stock solutions of each PAH $(300 \mathrm{mg} / \mathrm{L})$ were prepared in ethyl acetate and stored.

\section{Enrichment of bacterial consortium}

PAH dissolved in ethyl acetate was added to 250 $\mathrm{mL}$ conical flask and after the evaporation of ethyl acetate, the mineral medium $(100 \mathrm{~mL})$ was added. The bacterial consortium containing $5 \mathrm{~mL}$ of $10^{4}$ to $10^{5}$ $\mathrm{cfu} / \mathrm{mL}$ was added to the mineral medium containing PAH (phenanthrene) as sole carbon source. The conical flask was kept in shaker at $150 \mathrm{rpm}$ with $37^{\circ} \mathrm{C}$ as incubation temperature. After growth was visualized under microscope, $5 \mathrm{~mL}$ of enrichment culture was transferred to a fresh medium and incubated under the same conditions. Subsequent identical transfer of culture was performed in the respective $\mathrm{PAH}$ containing medium to enrich the bacterial consortium.

Studies on PAHs degradation by bacterial consortium

The PAHs were added in the medium at a concentration of $3 \mathrm{mg} / \mathrm{L}$. The bacterial consortium isolated from marine environment was grown and the bacterial count was checked everyday.

Cell morphology and motility of exponential growing liquid cultures were examined on freshly prepared wet mounts by light microscope. Plate counting was done on nutrient agar medium. The consortium was studied for its growth on PAHs with phenanthrene/fluorene as sole carbon source. A qualitative assay by the spray-plate method was used to check the degradation of PAH by the bacterial consortium. The clearing zones seen around the colonies indicated the utilization of PAH sprayed on the medium (Kiyohara et al., 1982). For the degradation study, the bacterial consortium was inoculated in mineral medium containing PAH. Different compositions used in the degradation of PAH were 1) Æedium + PAH + bacterial consortium; 2) medium + PAH and 3) medium + bacterial consortium where 2) and 3) served as controls.

Bacterial consortium was added at concentrations of $10^{4}$ to $10^{5} \mathrm{cfu} / \mathrm{mL}$ in the medium. The culture prepared in duplicates were incubated at $37^{\circ} \mathrm{C}$ in 
shaker at $150 \mathrm{rpm}$ and extracted at every $24 \mathrm{~h}$ time interval for 5 days. The culture samples were extracted twice with ethyl acetate $(\mathrm{v} / \mathrm{v})$ after acidification to $\mathrm{pH}$ 2.5 with $1 \mathrm{~N} \mathrm{HCl}$. The extracts were filtered through anhydrous sodium sulphate and condensed to $1 \mathrm{~mL}$ using rotavapour unit (Buchi, Germany) and analysed in a high performance liquid chromatography (HPLC). These condensed samples were used in TLC (thin layer chromatography) and gas chromatography- mass spectrometry (GC-MS) to analyse the metabolites formed during $\mathrm{PAH}$ degradation.

\section{HPLC analysis of PAH utilization}

The condensed sample was filtered through 0.2 $\mathrm{mm}$ syringe filter and analysed in a high performance liquid chromatography. HPLC analysis was performed with KNAUER, (Germany) unit equipped with PAH specific column (Ultrasep ES, B590/02, 250 $\times 4 \mathrm{~mm}$, Knauer, Germany) with UV-VIS detector connected to WINCHROME software, which was used to process the data. The mobile phase was acetonitrile. Standard solutions of different PAHs were used as reference. The flow rate of the mobile phase was maintained at $1 \mathrm{~mL} / \mathrm{min}$. The samples were injected one by one and the utilization rate of PAHs was calculated based on the peak area percent and retention time.

\section{Respiration test}

This study was conducted using mineral salts medium with both PAH and bacterial consortium; $\mathrm{PAH}+\mathrm{MSM}$ and MSM + bacterial consortium respectively served as controls. The test was performed in replicates. PAH (Phenanthrene- $3 \mathrm{mg}$ / L) dissolved in ethyl acetate was added in sterile saline bottles $(100 \mathrm{~mL})$. After evaporation of the solvent, $25 \mathrm{~mL}$ of mineral salts medium was added to the bottle. The bottles were sealed completely (air tight) with aluminium stopper. The culture was kept in a shaker at $150 \mathrm{rpm}$ at $37^{\circ} \mathrm{C}$. Samples were collected at $24 \mathrm{~h}$ time intervals and analysed for $\mathrm{CO}_{2}$ evolution in a Gas Chromatograph. Carbon dioxide content was measured with thermal conductivity detector using Porapak Q column (80/100 mesh, 2m) with an external standard. The carrier gas was helium and the column temperature was $50{ }^{\circ} \mathrm{C}$. The temperature of the injector and the detector was $100^{\circ} \mathrm{C}$. Samples $(250$ $\mu \mathrm{L}$ ) of the headspace gas from the culture flask were withdrawn with a gas-tight syringe and injected into the gas chromatograph for $\mathrm{CO}_{2}$ determination. The samples in the saline bottles were extracted and analysed in PAH specific column with HPLC for degradation of PAH in the medium.

\section{Metabolite formation-TLC and GC-MS}

During the degradation study, the different kinds of metabolites formed were identified using thin layer chromatography. The condensed samples were loaded on TLC plates using a $10 \mu \mathrm{L}$ capillary tube. The chromatograms were run in different solvents for migration of the PAH compounds. Different solvent mixtures such as: benzene/hexane (50:50), benzene/acetone (50:50) and benzene/acetone/acetic acid $(80: 10: 10)$ were used to identify the metabolites. After removing the plates from the solvents $2 \%$ Gibbs reagent was sprayed on the plate and seen under UV light at $265 \mathrm{~nm}$. A Hewlett-Packard 6890 gas chromatograph equipped with 5973 mass spectrometer with HP-5MS $(30 \mathrm{~m} \times 0.25 \mathrm{~mm} \mathrm{I.D} \times$ $0.25 \mu \mathrm{m}$ ) fuse-silica capillary column was used for analysis. The column temperature program was set at $100^{\circ} \mathrm{C}$ hold for $1 \mathrm{~min}, 15^{\circ} \mathrm{C} / \mathrm{min}$ to $160^{\circ} \mathrm{C}$ and $5^{\circ} \mathrm{C} /$ min to $300^{\circ} \mathrm{C}$ hold for $7 \mathrm{~min}$. The GC injector was held isothermally at $280^{\circ} \mathrm{C}$ with a splitless period of $3 \mathrm{~min}$. Helium was used as the carrier gas, at a flow rate of $1 \mathrm{ml} / \mathrm{min}$ by using electronic pressure control. The GC-MS interface temperature was maintained at $280{ }^{\circ} \mathrm{C}$. The MS was operated in electron impact (EI) ionization mode with electron energy of $70 \mathrm{eV}$ and the scan to determine appropriate masses for selected ion monitoring ranged from 50 to $500 \mathrm{amu}$ (atom to mass unit). Standards from Sigma Aldrich were used for the PAH (Phenanthrene/Fluorene) and their metabolites. GC-MS library search was used to confirm the metabolites without standards.

\section{Extraction and amplification of bacterial DNA}

DNA from the bacterial cells were extracted using Qiagen (QIAamp ${ }^{\circledR}$ DNA stool Mini kit Cat No.51504) DNA isolation kit. Using the protocol from manufacturer DNA was eluted in $200 \mu \mathrm{L}$ of AE buffer and stored at $4{ }^{\circ} \mathrm{C}$ for further use. To identify the bacterial strain, the isolated DNA was amplified using polymerase chain reaction (PCR). The concentrated DNA samples of the bacterial strains were amplified by polymerase chain reaction using thermal cycler (Mastercycler ${ }^{\circledR}$ personal, EppendorfAG, Germany). Amplification was performed using 25 pmol of 
forward primer (5'- TTTGATCCTGGCTCAG-3') and reverse primer (5'-AAGGAGGTGATCCAGCCGCA-3') to the total volume of $50 \mathrm{pmol}$. The PCR supermix (invitrogen Cat. No. 10572-014, USA) consisted of 22 $\mathrm{mM}$ tris- $\mathrm{HCl}$ (pH 8.4), $55 \mathrm{mM} \mathrm{KCl}, 1.65 \mathrm{mM} \mathrm{MgCl} 2,220$ $\mu \mathrm{M}$ dGTP, $220 \mu \mathrm{M}$ dATP, $220 \mu \mathrm{M}$ dTTP, $220 \mu \mathrm{M}$ dCTP and $22 \mathrm{U}$ recombinant Taq DNA polymerase $/ \mathrm{mL}$. The PCR supermix $(40 \mu \mathrm{L})$ was mixed with primers $(5 \mu \mathrm{L})$ and DNA $(5 \mu \mathrm{L})$ to a total volume of $50 \mu \mathrm{L}$ in $0.2 \mathrm{~mL}$ PCR tubes and loaded in thermal cycler. The PCR reactions occurred through an initial denaturation at $94^{\circ} \mathrm{C}$ for $3 \mathrm{~min}$, followed by 30 cycles of denaturation at $94^{\circ} \mathrm{C}$ for $1 \mathrm{~min}$, primer annealing at $60^{\circ} \mathrm{C}$ for $0.45 \mathrm{~min}$ and primer extension at $72^{\circ} \mathrm{C}$ for $2 \mathrm{~min}$. In the final step, the samples were incubated at $72^{\circ} \mathrm{C}$ for $10 \mathrm{~min}$. PCR amplification was verified by electrophoresis, performed in horizontal submarine apparatus with $1 \%$ agarose gel. TAE buffer was used as the tank buffer. Electrophoresis was carried out for $2 \mathrm{~h}$ at $50 \mathrm{~V}$. The gel was visualized in an UV illuminator. The PCR amplified DNA was analysed for its nucleotide sequence using $16 \mathrm{~S}$ rRNA sequential analysis.

\section{Denaturing gel gradient electrophoresis (DGGE)}

DGGE analysis was used to isolate and identify the number of strains present in the bacterial consortium. After isolating the strains, the polymerase chain reaction was used to amplify the DNA and further identified the bacterial strain using the nucleotide sequence. Polymerase chain reaction (PCR) amplification for DGGE was conducted with GC331F (CGCCCGCCGCGCGCGGCGGGCGGGGC G G G G G C G C G G G G G G T C C T A C G G G AGGCAGCAGT) and 797R (GGACTACCA GGGTATCT AATCCTGTT). In forward primer (GC331F) a 40 bp GC clamp is included as overhanging sequence. The PCR reactions occurred through an initial denaturation at $94^{\circ} \mathrm{C}$ for $10 \mathrm{~min}$, followed by 30 cycles of denaturation at $95^{\circ} \mathrm{C}$ for 15 $\mathrm{s}$, primer annealing at $60^{\circ} \mathrm{C}$ for $1 \mathrm{~min}$ and primer extension at $72{ }^{\circ} \mathrm{C}$ for $1 \mathrm{~min}$. In the final step, the samples were incubated at $72{ }^{\circ} \mathrm{C}$ for $10 \mathrm{~min}$. DGGE was performed with a continuous gradient of $40-70 \%$ of the denaturing agents urea and formamide. Gel contained $40 \%$ of polyacrylamide. Each well contained 1-3 $\mu \mathrm{g}$ DNA and equal volume of $2 \mathrm{x}$ gel loading dye was added to each sample. The electrophoresis tank was filled with $7 \mathrm{~L}$ of $1 \mathrm{x}$ TrisAcetate-Ethylenediamine tetraaceticacid (TAE) running buffer. DGGE was run at $60^{\circ} \mathrm{C}$ in a DCode Universal Mutation Detection System (Bio-Rad, Hercules, Ca, U.S.A.) at $130 \mathrm{~V}$ constant voltage for 8 h. Gel was stained with $250 \mathrm{~mL}$ of running buffer and $25 \mu \mathrm{L} 10 \mathrm{mg} / \mathrm{mL}$ of ethidium bromide for $5-15$ min. After staining, the gel was transferred into a dish containing $250 \mathrm{~mL}$ of $1 \mathrm{x}$ running buffer and destain for 5-20 min. The gels were scanned in a GelDoc system (Bio-Rad).

\section{Biochemical analysis}

The bacterial strains present in the consortium were isolated and analyzed for phenotypic characters using KB003: Hi24 "Enterobacteriaceae identification kit", (Himedia, India).

\section{$16 S$ rRNA sequential analysis of PAH degrading} bacterial consortium

The cyclic sequencing reaction was performed using BigDye terminator V3.1 cycle sequencing kit containing Ampli Tac DNA polymerase (Applied biosystems, $\mathrm{P} / \mathrm{N}: 4337457$ ). The sequencing reaction mix was prepared by adding $1 \mu \mathrm{L}$ of BigDyeV3.1, 2 $\mu \mathrm{L}$ of $5 \mathrm{x}$ sequencing buffer and $1 \mu \mathrm{L}$ of $50 \%$ DMSO. To $4 \mu \mathrm{L}$ of sequencing reaction mix 4 Pico moles of primer $(2 \mu \mathrm{L})$ and sufficient amount of purified PCR product was added. The constituted reaction was denatured at $95^{\circ} \mathrm{C}$ for $5 \mathrm{~min}$. Cycling began with denaturing at $95^{\circ} \mathrm{C}$ for $30 \mathrm{~s}$, annealing at $52^{\circ} \mathrm{C}$ for $30 \mathrm{~s}$ and extension for $4 \mathrm{~min}$ at $60^{\circ} \mathrm{C}$ and the cycle was repeated for a total of 30 times in MWG thermocycler (MWG BioTech, Germany). The reaction was then purified on sephadex plate (Edge biosystems) by centrifugation to remove unbound labelled and unlabelled nucleotides and salts. The purified reaction was loaded on to the 96 capillary ABI 3700 automated DNA analyzer and electrophoresis was carried out for $4 \mathrm{~h}$. The nucleotide sequences are registered in the computer attached with the ABI 3700 DNA analyzer. The nucleotide sequences obtained from the ABI DNA analyzer were identified using BLAST (Basic Local Alignment Search Tool) software available in NCBI (National Centre for Biotechnology Information) website (www.ncbi.nlm.nih.gov). After editing the sequence, analysed with BLAST software to identify the specific type of bacteria corresponding to the nucleotide sequence. 


\section{RESULTS AND DISCUSSION}

Biodegradation of PAHs by the bacterial consortium at $30 \mathrm{~g} / \mathrm{L} \mathrm{NaCl}$ concentration

Low molecular weight PAHs are compounds with less than three benzene rings and having a molecular weight in the range of $128-178 \mathrm{~g} / \mathrm{mol}$ (eg : naphthalene, fluorene, phenanthrene and anthracene). The bacterial consortium utilized naphthalene ( $3 \mathrm{mg} / \mathrm{L}$ ) as sole carbon source. The cell count of the consortium increased from $5 \times 10^{4} \mathrm{cfu} / \mathrm{mL}$ to $6 \times 10^{9} \mathrm{cfu} / \mathrm{mL}$ in 4 days. Naphthalene was readily degraded by the consortium and nearly $98 \%$ of the compound was degraded in 4 days (Fig. 1). Fluorene consists of two benzene rings coupled with a pentagonal ring (cyclopentane ring) and listed as a priority pollutant by Environmental Protection Agency (EPA) (Gomes et al., 2006). In this

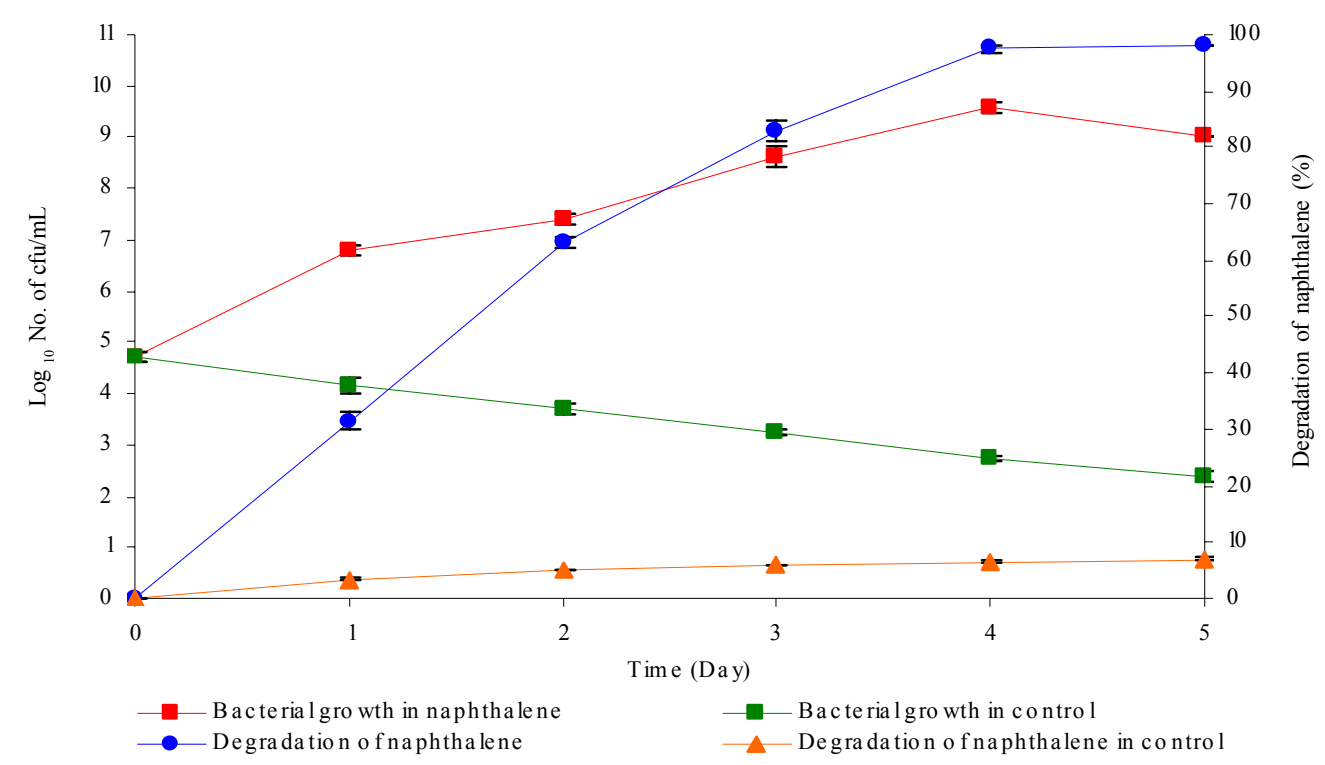

Fig. 1: Degradation of naphthalene $(3 \mathrm{mg} / \mathrm{L})$ by halotolerant bacterial consortium at $30 \mathrm{~g} / \mathrm{L}$ of $\mathrm{NaCl}$ concentration

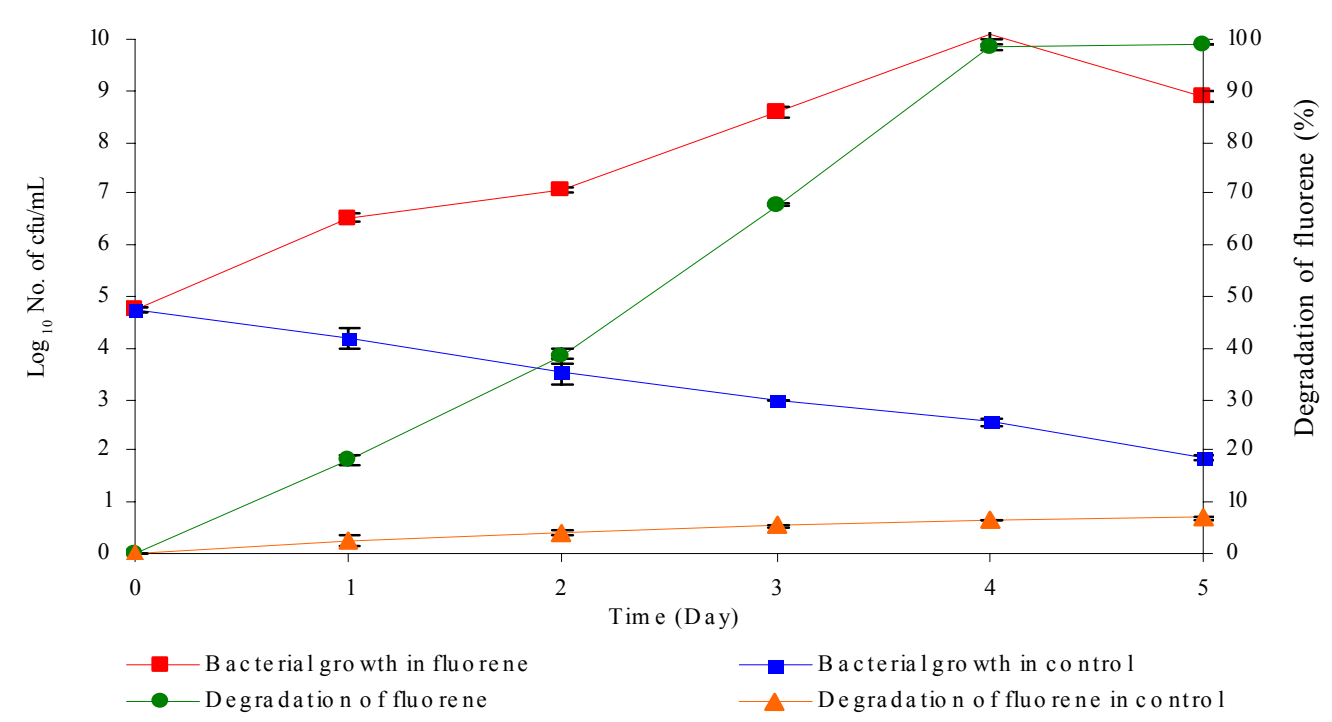

Fig. 2: Degradation of fluorene $(3 \mathrm{mg} / \mathrm{L})$ by halotolerant bacterial consortium at $30 \mathrm{~g} / \mathrm{L}$ of $\mathrm{NaCl}$ concentration 


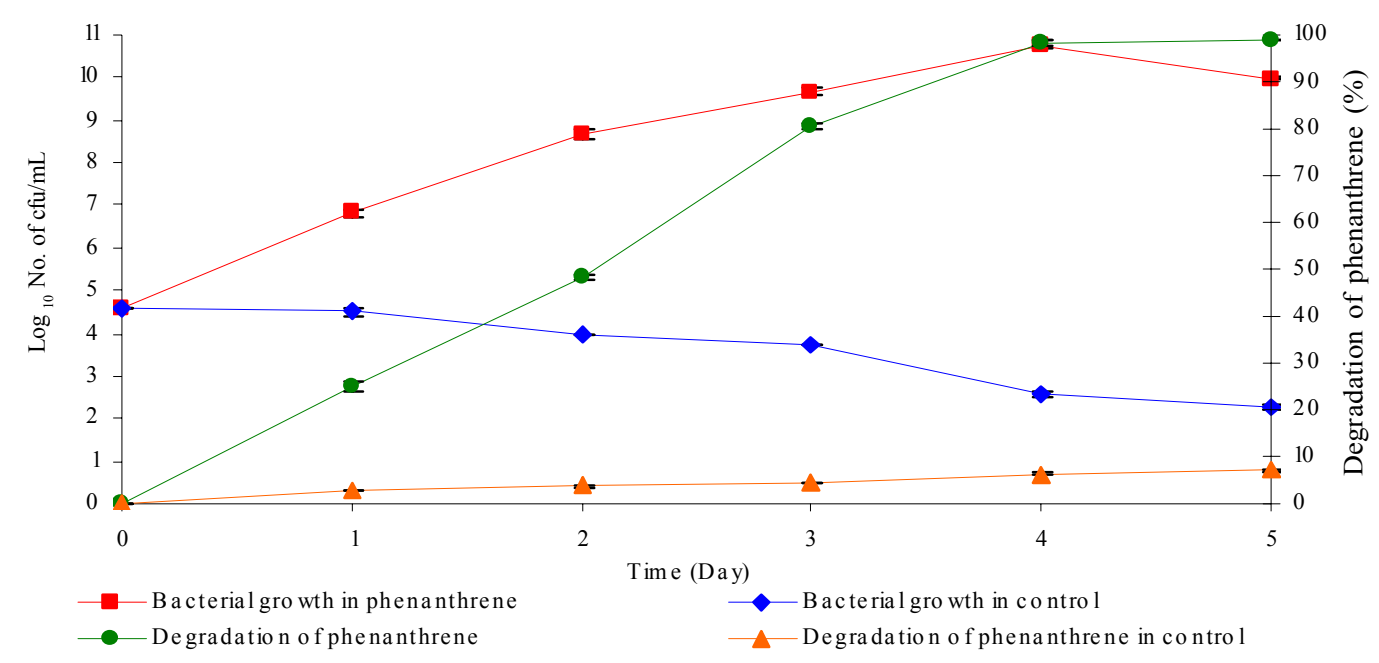

Fig.3: Degradation of phenanthrene ( $3 \mathrm{mg} / \mathrm{L}$ ) by halotolerant bacterial consortium at $30 \mathrm{~g} / \mathrm{L}$ of $\mathrm{NaCl}$ concentration

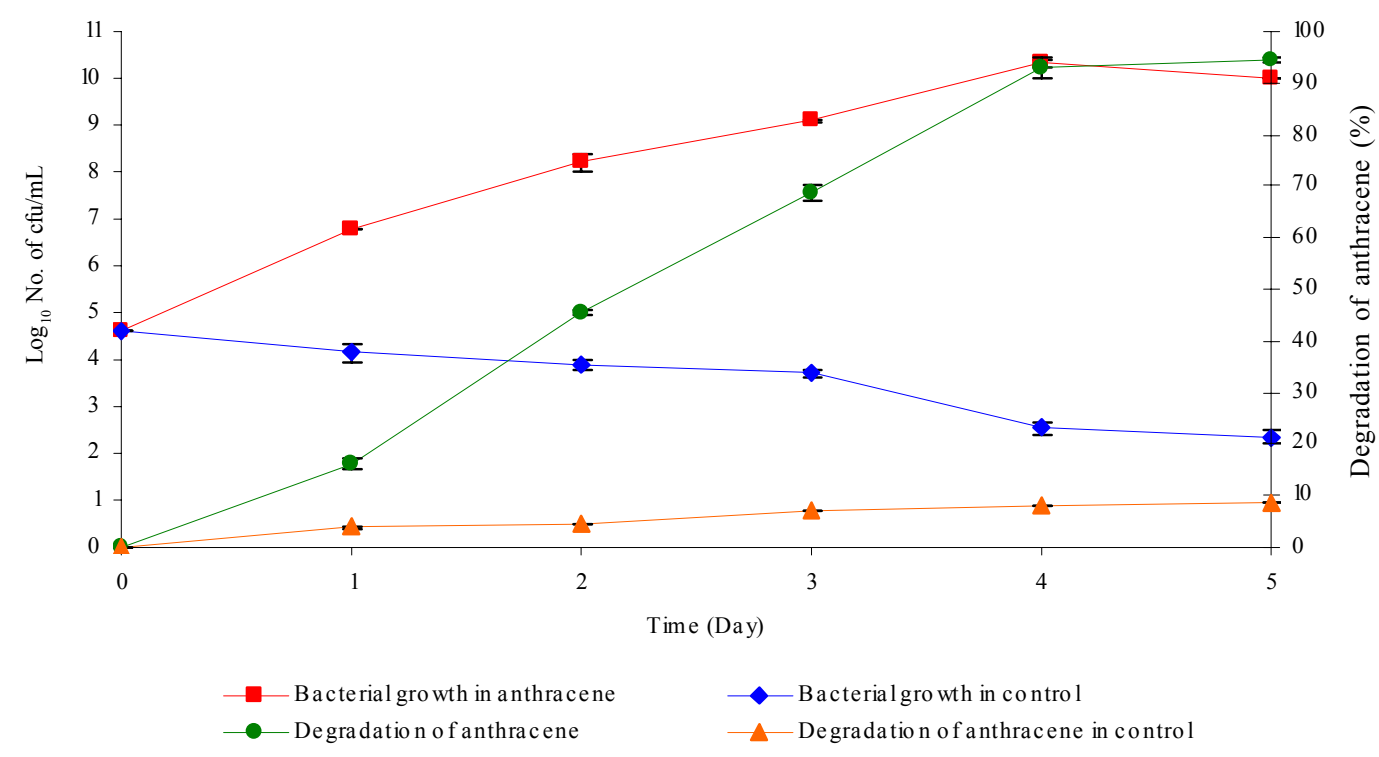

Fig. 4: Degradation of anthracene $(3 \mathrm{mg} / \mathrm{L}$ ) by halotolerant bacterial consortium at $30 \mathrm{~g} / \mathrm{L}$ of $\mathrm{NaCl}$ concentration

study, the consortium utilized fluorene $(3 \mathrm{mg} / \mathrm{L})$ as the sole carbon source and showed a maximum degradation of $99 \%$. The cell count of the consortium increased from $6 \times 10^{4}$ to $2 \times 10^{10} \mathrm{cfu} / \mathrm{mL}$ in 4 days (Fig 2). The bacterial consortium was initially acclimatized on phenanthrene $(3 \mathrm{mg} / \mathrm{L})$ at $30 \mathrm{~g} / \mathrm{L}$ of $\mathrm{NaCl}$ concentration. The cell count of the consortium increased from $5 \times 10^{4}$ to $7 \times 10^{10} \mathrm{cfu} / \mathrm{mL}$ in 4 days. Nearly $50 \%$ of phenanthrene was degraded in 2 days and $100 \%$ degradation was recorded in 4 days. The degradation of phenanthrene was $80 \%$ on the $3^{\text {rd }}$ day Fig. 3 . The bacterial consortium showed $99 \%$ degradation on fluorene and phenathrene at $30 \mathrm{~g} / \mathrm{L}$ of $\mathrm{NaCl}$ concentration in 4 days. The consortium utilized anthracene $(3 \mathrm{mg} / \mathrm{L})$ at a saline concentration of $30 \mathrm{~g} / \mathrm{L}$. The cell count of the consortium increased from $5 \times 10^{4} \mathrm{cfu} / \mathrm{mL}$ to $7 \times 10^{10}$ 
$\mathrm{cfu} / \mathrm{mL}$ in 4 days. The consortium potently degraded anthracene $49 \%$ in 2 days and $95 \%$ in 4 days (Fig 4).

The results were analysed for reproducibility of the PAHs degradation by the bacterial consortium using phenanthrene and fluorine showed no major change in the percent degradation (97-98\%) was observed.

The bacterial consortium isolated from the marine environment was analysed for its growth on PAHs. Preliminary studies using PAH clearing zone by the bacterial consortium in mineral salts medium confirmed the utilization of PAH.

The results showed that the consortium potently degraded PAHs almost completely (>95\%) in 4 days at $30 \mathrm{~g} / \mathrm{L} \mathrm{NaCl}$ concentration.

Identification of metabolites formed during biodegradation of $\mathrm{PAH}$ (phenanthrene and fluorene)

The formation of metabolites during mineralization of phenanthrene was identified by thin layer chromatography and then by gas chromatography-mass spectral analysis. The analysis showed the presence of four metabolites namely 1-hydroxy-2-naphthoic acid (m/z, 202), phenanthrene-dihydrodiol $(\mathrm{m} / \mathrm{z}, 356)$, dihydroxy phenanthrene $(\mathrm{m} / \mathrm{z}, 354)$ and phthalic acid $(\mathrm{m} / \mathrm{z}, 310)$ during the degradation of phenanthrene. During fluorene degradation by the bacterial consortium, the analysis showed six peaks in which two peaks were confirmed as monohydroxy fluorene $(\mathrm{m} / \mathrm{z}, 254)$ and phthalic acid (m/z, 310). Monohydroxy fluorene and phthalic acid were formed during fluorene degradation by the bacterial consortium. The metabolite phthalic acid formed during phenanthrene degradation was also present in fluorene degradation confirms complete degradation (Table 1).

\section{Mineralization of phenanthrene}

In the present study, rate of PAH (Phenanthrene) degradation was calculated as the ratio of the amount of substrate degraded in test bottles, to the amount of substrate recovered in the control bottles. The total $\mathrm{CO}_{2}$ production was the difference between the final quantities of $\mathrm{CO}_{2}$ in the test bottle and in the hydrocarbon free bottle (control bottle). The mineralization yield was graphically plotted as the carbon ratio of the net $\mathrm{CO}_{2}$ produced (ppmv) to the percent of PAH consumed. The results showed that the bacterial consortium with phenanthrene as sole carbon source produced higher levels of $\mathrm{CO}_{2}(1338$ ppmv) compared to the controls (181 ppmv) in MSM in 4 days. After four days, carbon dioxide evolution was absent. Along with $\mathrm{CO}_{2}$ evolution, the residual phenanthrene present in the medium was analysed in order to correlate percent degradation with $\mathrm{CO}_{2}$ evolution. In the control flask during HPLC analysis, around $2.8 \mathrm{mg} / \mathrm{L}$ of phenanthrene remained unutilized. The flask with bacterial consortium showed $99 \%$ phenanthrene degradation in 4 days. The bacterial consortium showed significant $\mathrm{CO}_{2}$ evolution (1066 ppmv) and phenanthrene degradation (49\%) was obtained in 2 days (Fig 5). Then, it was confirmed that phenanthrene was almost completely degraded by the bacterial consortium.

\section{Biodegradation of PAHs using bacterial consortium at $60 \mathrm{~g} / \mathrm{LNaCl}$ concentration}

Further the bacterial consortium was examined for its growth on PAHs at $60 \mathrm{~g} / \mathrm{L}$ of $\mathrm{NaCl}$ concentration. The degradation decreased due to increase in salt concentration and the consortium was able to degrade only 45 and $43 \%$ of phenanthrene and fluorene, respectively at $60 \mathrm{~g} / \mathrm{L}$ $\mathrm{NaCl}$ concentration in 4 days. With anthracene and

Table 1: GC-Mass spectral analysis of phenanthrene and fluorene metabolites detected during its degradation by bacterial consortium

\begin{tabular}{clll}
\hline Sl.No. & \multicolumn{1}{c}{ Name of the metabolite } & Retention time $(\mathrm{min})$ & \multicolumn{1}{c}{$\mathrm{m} / \mathrm{z}$ of fragment ions(\% relative abundance) } \\
\hline $\begin{array}{c}\text { Phenanthrene } \\
\text { 1. }\end{array}$ & Phenanthrene-dihydrodiol & 21.65 & $356\left(35, \mathrm{M}^{+}\right), 341(44), 73(100)$ \\
2. & Dihydroxy phenanthrene & 19.73 & $354(39 \mathrm{M}+), 339(4), 266(15), 251(5), 236(9), 73(100)$ \\
3. & 1-hydroxy-2-naphthoic acid & 28.67 & $202\left(\mathrm{M}^{+}, 48\right), 170(100), 142(16), 114(69)$ \\
4. & Phthalic acid & 11.34 & $310\left(8, \mathrm{M}^{+}\right), 295(100), 251(3), 221(15), 140(10), 103$ \\
& & & $(13)$ \\
Fluorene & & 12.29 & $254\left(53, \mathrm{M}^{+}\right), 239(12), 165(100)$ \\
1. & Monohydroxy fluorene & 11.34 & $310\left(8, \mathrm{M}^{+}\right), 295(100), 251(3), 221(15), 140(10), 103$ \\
2. & Phthalic acid & & \\
\hline
\end{tabular}


naphthalene as sole carbon source, at $60 \mathrm{~g} / \mathrm{L} \mathrm{NaCl}$ concentration, the bacterial consortium was able to degrade $39 \%$ and $42 \%$ in 4 days.

Influence of additional substrate in PAHs degradation (Yeast extract $0.2 \mathrm{~g} / \mathrm{L}$ at $60 \mathrm{~g} / \mathrm{L} \mathrm{NaCl} \mathrm{concentration)}$

In this study, the influence of yeast extract $(0.2$ $\mathrm{g} / \mathrm{L}$ ) as an additional substrate was examined in the degradation of PAHs by the bacterial consortium. Yeast extract is the water soluble portion of autolyzed yeast containing vitamins, nitrogen, amino acids and carbon for bacterial growth. The controls used in the study at $60 \mathrm{~g} / \mathrm{L}$ of $\mathrm{NaCl}$ concentration with yeast extract were i) medium + bacterial consortium + yeast extract and ii) medium + PAH. Yeast extract significantly enhanced the growth of bacterial consortium on PAHs at $60 \mathrm{~g} / \mathrm{L}$ of $\mathrm{NaCl}$. Addition of yeast extract potently increased the growth and degradation of the PAHs. With naphthalene in the presence of yeast extract, the bacterial consortium showed $78 \%$ degradation. The viable cell count increased from $7 \times 10^{4}$ to $2 \times 10^{9} \mathrm{cfu} / \mathrm{mL}$ in 4 days (Fig. 6). The bacterial consortium degraded $85 \%$ of fluorene with a corresponding increase in the bacterial cells from $8 \times 10^{4}$ to $2 \times 10^{9} \mathrm{cfu} / \mathrm{mL}$ in 4 days (Fig. 7). Phenanthrene, when used as sole carbon source underwent degradation up to $87 \%$ with bacterial cell count increased from $7 \times 10^{4}$ to $3 \times 10^{9}$ cfu/mL in 4 days (Fig. 8).
The bacterial consortium was able to degrade 74 $\%$ of anthracene in 4 days. During anthracene degradation the bacterial cell count increased from 6 $\times 10^{4}$ to $2 \times 10^{9} \mathrm{cfu} / \mathrm{mL}$ (Fig. 9). In the control, the consortium grows with the available yeast extract, observed as an increase in growth up to 3 days and reached decline phase on the $4^{\text {th }}$ day. In the consortium with yeast extract and $\mathrm{PAH}$, increase in growth was observed during $4^{\text {th }}$ day. Addition of yeast extract enhanced the biodegradation of PAHs at 60 $\mathrm{g} / \mathrm{L}$ of $\mathrm{NaCl}$ concentration.

\section{Biodegradation of PAHs (fluorene and phenanthrene) at different concentrations}

The extend of PAHs degradation by the bacterial consortium was studied using phenanthrene and fluorene as representative compounds at 5, 10, 20, 50 and $100 \mathrm{ppm}$ concentrations. Phenanthrene at 5, 10, 20 ppm was almost completely degraded ( $>95 \%$ ) by the bacterial consortium in 4 days. When the concentration of phenanthrene increased to $50 \mathrm{ppm}$, the percent degradation decreased to $89 \%$ and at $100 \mathrm{ppm}$ degradation was $74 \%$ in 4 days. In the case of fluorene, similar results were obtained as that for phenanthrene at the concentration of 5, 10,20 ppm. At high concentrations (50 and $100 \mathrm{ppm}$ ) phenantherene and fluorene had the same degradation (data not shown). The consortium was able to degrade phenanthrene and fluorene at $30 \mathrm{~g} / \mathrm{Lof} \mathrm{NaCl}$ concentration without any additional carbon source.



Fig. 5: $\mathrm{CO}_{2}$ evolution during degradation of phenanthrene $(3 \mathrm{mg} / \mathrm{L})$ by bacterial consortium 
Int. J. Environ. Sci. Tech., 7 (4), 639-652, Autumn 2010

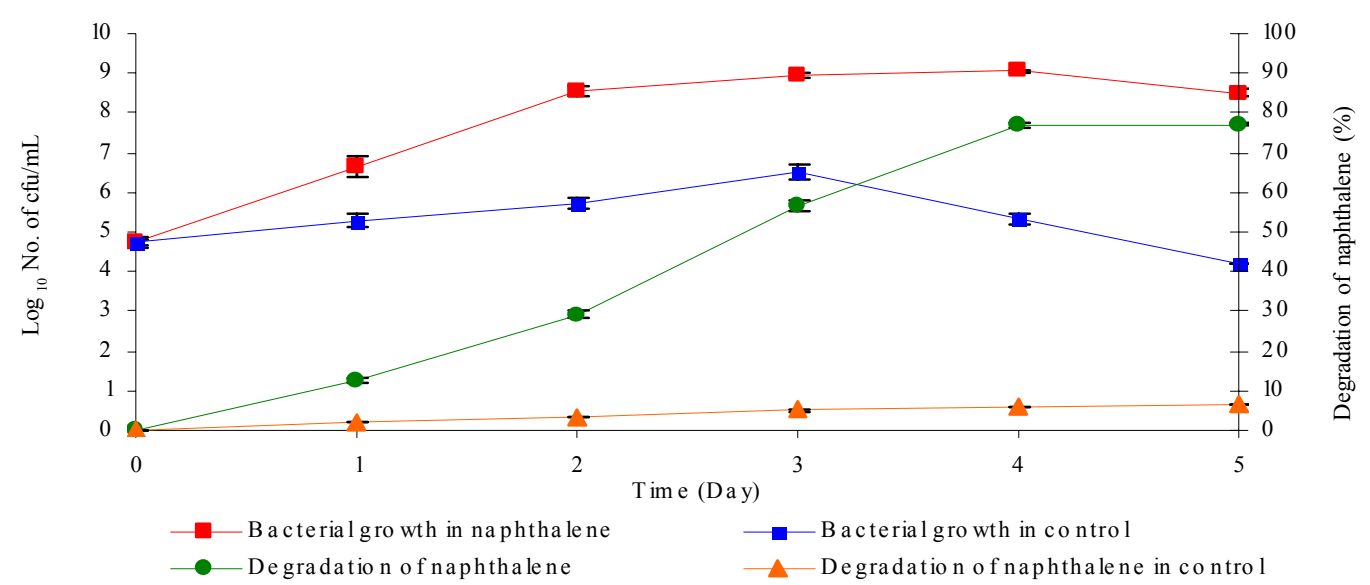

Fig. 6. Degradation of naphthalene $(3 \mathrm{mg} / \mathrm{L}$ ) by halotolerant bacterial consortium at $60 \mathrm{~g} / \mathrm{L}$ of $\mathrm{NaCl}$ concentration in the presence of yeast extract $(0.2 \mathrm{~g} / \mathrm{L})$

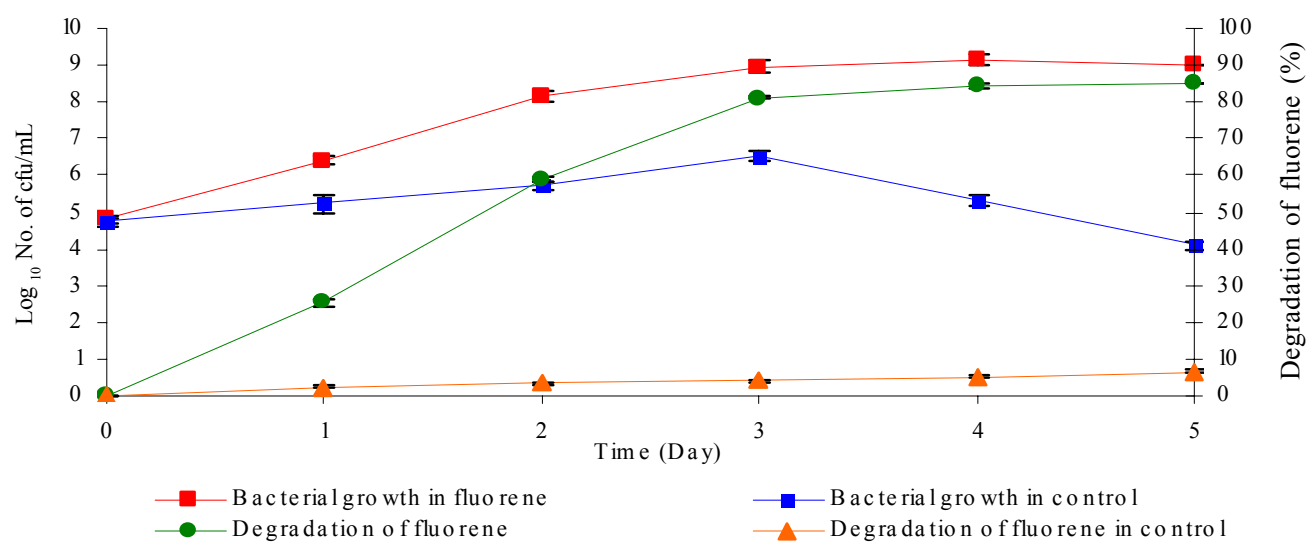

Fig.7: Degradation of fluorene $(3 \mathrm{mg} / \mathrm{L})$ by halotolerant bacterial consortium at $60 \mathrm{~g} / \mathrm{L}$ of $\mathrm{NaCl}$ concentration in the presence of yeast extract $(0.2 \mathrm{~g} / \mathrm{L})$



Fig. 8: Degradation of phenanthrene $(3 \mathrm{mg} / \mathrm{L})$ by halotolerant bacterial consortium at $60 \mathrm{~g} / \mathrm{L}$ of $\mathrm{NaCl}$ concentration in the presence of yeast extract $(0.2 \mathrm{~g} / \mathrm{L})$ 
Identification of strains in the bacterial consortium

Through DGGE analysis, it was confirmed that the PAHs degrading consortium consists of three bacterial strains namely VA1, VA2 and VA3. The bacterial strains present in the consortium were isolated and identified using phenotypic and phylogenetic analysis.

\section{Description of VA1 strain (Ochrobactrum sp.)}

Phylogenetic analysis based on nucleotide sequences from VA1 strain showed a maximum of 98 $\%$ identity towards Ochrobactrum sp. The strain is gram negative, rod shaped, aerobic and oxidase positive. The strain grows well at temperature of $37^{\circ} \mathrm{C}$ and $\mathrm{pH} 7.8$. When the strain was analysed for physiological characters, the strain showed negative result towards Ortho nitro phenylene $\beta$ galactopyranoside, phenylalanine deamination, methyl red, voges proskauer and indole reactions. The strain utilized 9 out of 13 carbon sources (serial number. 13 to 25). Arabinose, adonitol, trehalose and lactose are the carbon sources which were not utilized by the strain (Table 2).

\section{Description of VA2 strain (Enterobacter cloacae)}

The bacterial isolate VA2 showed $99 \%$ identity towards Enterobacter cloacae. The strain grows well at temperature of $37^{\circ} \mathrm{C}$ and $\mathrm{pH}$ 7.8. The strain is gram- negative rod shaped, aerobic and oxidase positive. The phenotypic characters of the strain VA2 showed negative for Lysine decarboxylase, Phenylalanine deamination, $\mathrm{H}_{2} \mathrm{~S}$ Production, Methyl red, Indole tests. The strain utilized 12 out of 13 carbon sources. Adonitol was the only carbon source which was not utilized by the strain (Table 2).

\section{Description of VA3 strain (Stenotrophomonas maltophilia)}

The isolate VA3 from the bacterial consortium showed $98 \%$ identity towards Stenotrophomonas maltophilia. Isolate VA3 is also gram negative, aerobic and oxidase positive. The strain grows well at $37^{\circ} \mathrm{C}$ and $\mathrm{pH} 7.8$. The phenotypic tests showed: Ortho nitro phenylene â-galactopyranoside, Urease, Phenylalanine deamination, Methyl red, Voges Proskaures, Indole - negative. The strain utilized 10 out of 13 carbon sources. Adonitol, raffinose and glucose was unutilized by the strain VA3 (Table 2).
Thus, the results from phylogenetic and phenotypic analysis showed that isolate VA3 belongs to Stenotrophomonas maltophili. The nucleotide sequences of the three bacterial strains were submitted to Gen Bank and their respective accession numbers are VA1 (EU722312), VA2 (EU722313) and VA3 (EU722314).

In the present study, the halotolerant consortium potently degraded naphthalene (98\%), fluorene (99 $\%$ ), phenanthrene (99\%) and anthracene (95\%), respectively at $30 \mathrm{~g} / \mathrm{L}$ of $\mathrm{NaCl}$ concentration in 4 days. The biodegradation of PAHs by the bacterial consortium showed $>95 \%$ degradation of low molecular weight PAHs. Tam et al. (2002) studied phenanthrene degradation by bacterial consortium isolated from mangrove sediment. The bacterial consortium degraded phenanthrene up to $47 \%$ at $20 \mathrm{~g} /$ Lof salinity, but growth and rate of phenanthrene degradation was influenced by salinity. At higher salinity $(35 \mathrm{~g} / \mathrm{L})$, the growth and biodegradation by bacterial consortium was inhibited. Addition of glucose as additional carbon source at $35 \mathrm{~g} / \mathrm{L}$ of $\mathrm{NaCl}$ increased the degradation from 35.6 to $45 \%$. Salinity plays an important role in PAHs degradation. Diaz et al. (2000) isolated two novel and versatile bacterial consortia for the biodegradation of hydrocarbons. Bacterial consortium isolated from mangrove roots was efficient in degrading phenanthrene $(50 \%)$ and naphthalene $(80 \%)$ compared to the consortium from cormorant oil field in North Sea. The consortium was able to degrade both aliphatic and aromatic hydrocarbons in crude oils in seawater $(35 \mathrm{~g} / \mathrm{LNaCl})$ saline concentration. Salinities over twice than that of normal seawater decreased the biodegradation rates. The optimum salt concentration for hydrocarbon degradation was $20 \mathrm{~g} / \mathrm{Land} 40 \mathrm{~g} / \mathrm{L}$ In the present study, degradation of PAHs was confirmed by analyzing the metabolites formed and carbon dioxide evolved during the degradation of PAHs. During phenanthrene degradation, phenanthrene-dihydrodiol, dihydroxy phenanthrene, 1-hydroxy-2-naphthoic acid and phthalic acid were formed. Similar metabolites such as cisphenanthrene-1,2-dihydrodiol, 1-Hydroxy-2naphthoic acid and phthalic acid formed during phenanthrene degradation were reported by Seo et al. (2007). Similarly, degradation of phenanthrene by 


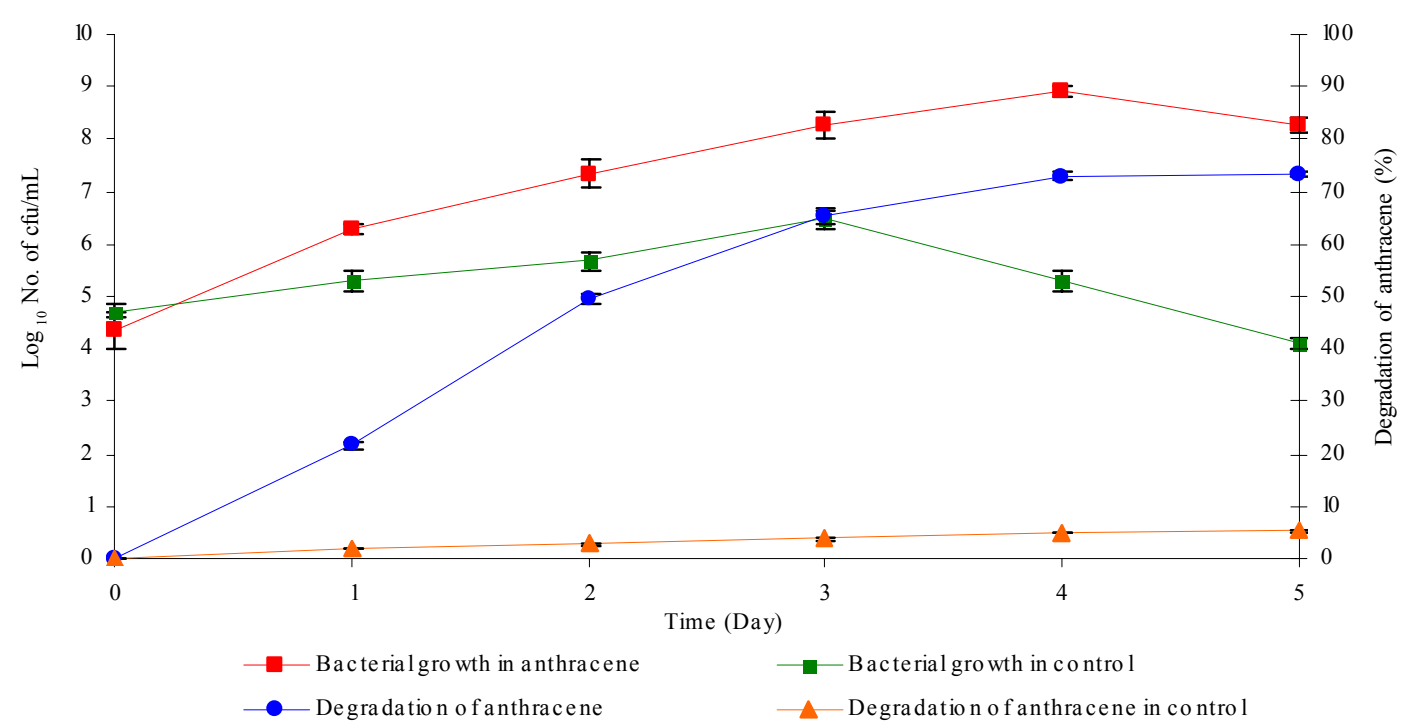

Fig. 9. Degradation of anthracene $(3 \mathrm{mg} / \mathrm{L})$ by halotolerant bacterial consortium at $60 \mathrm{~g} / \mathrm{L}$ of $\mathrm{NaCl}$ concentration in the presence of yeast extract $(0.2 \mathrm{~g} / \mathrm{L})$

Table 2: Phenotypic characterization of VA1, VA2 and VA3 strains

\begin{tabular}{|c|c|c|c|c|}
\hline S.No. & Name of the Biochemical test & VA1 & VA2 & VA3 \\
\hline 1. & Oxidase & + & + & + \\
\hline 2. & $\begin{array}{l}\text { Ortho nitro phenylene } \beta \text { - } \\
\text { galactopyranoside }\end{array}$ & - & + & - \\
\hline 3. & Lysine decarboxylase & + & - & + \\
\hline 4. & Ornithine & + & + & + \\
\hline 5. & Urease & + & + & - \\
\hline 6. & Phenylalanine deamination & - & - & - \\
\hline 7. & Nitrate reduction & - & + & + \\
\hline 8. & $\mathrm{H}_{2} \mathrm{~S}$ Production & + & - & + \\
\hline 9. & Citrate Utilization & + & + & + \\
\hline 10. & Methyl red & - & - & - \\
\hline 11. & Voges Proskaures & - & + & - \\
\hline 12. & Indole & - & - & - \\
\hline 13. & Malonate & + & + & + \\
\hline 14. & Esculin & + & + & + \\
\hline 15. & Arabinose & - & + & + \\
\hline 16. & Xylose & + & + & + \\
\hline 17. & Adonitol & - & - & - \\
\hline 18. & Rhamnose & + & + & + \\
\hline 19. & Cellobiose & + & + & + \\
\hline 20. & Melibiose & + & + & + \\
\hline 21. & Saccharose & + & + & + \\
\hline 22. & Raffinose & + & + & - \\
\hline 23. & Trehalose & - & + & - \\
\hline 24. & Glucose & + & + & + \\
\hline 25. & Lactose & - & + & + \\
\hline
\end{tabular}

bacteria and the metabolites formed during the degradation was reported by other workers (Pinyakong et al., 2000; Moody et al., 2001; Kang et al., 2003; Kim et al., 2005). Wang et al. (2008) reported phenanthrene degradation by microbial consortium under saline condition with phthalic acid as metabolite. During mineralization of PAHs, the amount of $\mathrm{CO}_{2}$ evolved indicates the extent of degradation (Solano-Serena et al., 1999). Bouchez et al. (1996) reported that complete degradation of PAH results in the evolution of $\mathrm{CO}_{2}$, formation of biomass and water soluble metabolites. Since most of the aromatic hydrocarbons are toxic compounds, complete degradation depending on the versality of the organisms, would produce harmless products such as $\mathrm{CO}_{2}$ and water as the end products. The bacterial consortium used in the study completely mineralized phenanthrene $(3 \mathrm{ppm})$ with equal amount of carbondioxide (1338 ppmv) released, the residual phenanthrene indicates $99 \%$ of phenathrene degradation. The ratio between the amount of carbon dioxide produced and residual hydrocarbons, gives a complete picture of the hydrocarbon degradation 
(Penet et al., 2004). Salinity plays an important role in the biodegradation of PAHs. In the present study, when salinity of mineral salt medium increased to 60 $\mathrm{g} / \mathrm{L}$ of $\mathrm{NaCl}$ concentration, a decrease in percent degradation of PAHs was observed. The consortium was able to degrade 39 to $45 \%$ of PAHs at $60 \mathrm{~g} / \mathrm{L}$ of $\mathrm{NaCl}$ concentration. Several researchers have studied the on role of salinity in PAH degradation and the importance of additional substrate. Atlas (1981) reported that phenanthrene biodegradation was influenced by a number of environmental factors such as salinity and addition of carbon and nutrients. Yuan et al. (2000) reported that increase in salinity and depletion of nutrients inhibits the growth of the bacterial cells. To support the growth of bacterial cells, nutrients such as glucose, yeast extract and acetate were added. Tehrani et al. (2009) reported the effect of salinity on biodegradation of PAHs of heavy crude oil. Head et al. (2006) described the importance of additional nutrients in the bioremediation of petroleum hydrocarbons. Kumar et al., (2007) isolated a bacillus strain, able to sustain at 0-100 g/Lof $\mathrm{NaCl}$ and 30-45 ${ }^{\circ} \mathrm{C}$. The biosurfactant production by the organism emulsified a range of hydrocarbons with hexadecane as the best substrate and toluene as the poorest. Mixture of PAHs (0.02 \%) + diesel, gas oil, alkanes, crude oil and kerosene $(0.2 \%)$ were used in the experiment along with Basal salt medium (Yeast extract$2.5 \mathrm{~g} / \mathrm{L}+$ trace elemental solution + crude oil $2 \% \mathrm{w} / \mathrm{v})$. The strain was able to utilize pyrene (64\%), phenanthrene (69 \%) and dibenzothiophene (72\%) as sole substrates at $100 \mathrm{~g} / \mathrm{L}$ of $\mathrm{NaCl}$ in 2 weeks. Kumar et al. (2007) also detailed the importance of additional substrate during PAHs degradation and biosurfactant production under high saline condition. Nicolson and Fathepure (2004) reported addition of yeast extract to halophilic and halotolerant bacteria enhanced the biodegradation of benzene, toluene, ethylbenzene and xylene (BTEX) compounds.In the present study, with yeast extract at $60 \mathrm{~g} / \mathrm{L}$ of $\mathrm{NaCl}, 87 \%$ and $85 \%$ of phenanthrene and fluorene was degraded in 4 days by the bacterial consortium. Naphthalene and anthracene degradation was $78 \%$ and $74 \%$, respectively in 4 days.

The consortium significantly degraded PAHs ( $>74$ $\%)$ in a time period of 4 days at $60 \mathrm{~g} / \mathrm{L}$ of $\mathrm{NaCl}$ concentration with yeast extract as additional nutrient. Thus, from this study, it was concluded that the growth of hydrocarbon degrading bacteria and hydrocarbon degradation can be strongly enhanced by the addition of nutrients (Yeast extract). The addition of nitrogen and phosphate was proved to be an effective bioremediation treatment on several shorelines (Swannell et al. 1996; Venosa et al. 1996; Swannell et al., 1999). The present study showed degradation of PAHs by bacterial consortium at two different salt concentrations (30 g/L and $60 \mathrm{~g} / \mathrm{L}$ ).

The growth and degradation at $30 \mathrm{~g} / \mathrm{L}$ on PAHs (> $95 \%$ ) was comparatively higher than in $60 \mathrm{~g} / \mathrm{L}$ of $\mathrm{NaCl}$ concentration (39 to $45 \%$ ). The consortium was also able to degrade PAHs (fluorene and phenanthrene) at different concentrations (5, 10, 20, 50 and 100 ppm). Further studies where conducted on different concentrations (5, 10, 20, 50 and 100 ppm) of PAHs (fluorene and phenanthrene) at $30 \mathrm{~g} / \mathrm{L}$ of $\mathrm{NaCl}$ concentration. Interestingly, the bacterial consortium was able to grow and degrade PAHs upto $100 \mathrm{ppm}$ at $30 \mathrm{~g} / \mathrm{L}$ of $\mathrm{NaCl}$ concentration without any additional nutrients (data not shown). At $60 \mathrm{~g} / \mathrm{L}$ of $\mathrm{NaCl}$ concentration with yeast extract the consortium was found to potently degrade PAHs.

Thus, the consortium with Ochrobactrum sp. (EU722312), Enterobacter cloacae (EU722313) and Stenotrophomonas maltophilia (EU722314) could be employed in the degradation of PAHs contaminated marine environment.

\section{CONCLUSION}

The bacterial consortium enriched from the marine environment was capable of degrading PAHs at $30 \mathrm{~g} / \mathrm{L}$ and $60 \mathrm{~g} / \mathrm{L}$ of $\mathrm{NaCl}$ concentration. With yeast extract as additional nutrient at $60 \mathrm{~g} / \mathrm{L}$ of $\mathrm{NaCl}$ concentration the bacterial consortium was able to degrade PAHs. The study proved that addition of nutrients under saline condition also plays an important role in PAH degradation. Thus, the present study gives prominent idea about the promising PAHs degrading halotolerant bacterial consortium under saline condition.

\section{ACKNOWLEDGEMENTS}

The authors gratefully acknowledge the assistance rendered by Mr. Thirunavukkarasu, Laboratory Assistant in Centre for Environmental Studies, Anna University, Chennai, India during the study.

\section{REFERENCES}

Agbozu, I. E.; Opuene, K., (2009). Occurrence and Diagenetic Evolution of Perylene in the Sediments of Oginigba Creek, 
Southern Nigeria. Int. J. Environ. Res., 3 (1), 117-120 (4 pages).

Atlas, R., (1981). Microbial degradation of petroleum hydrocarbons: An environmental perspective. Microbiol. Rev., 45 (1), 180-209 (30 pages).

Atlas, R.; Bragg J., (2009). Bioremediation of marine oil spills: When and when not-the Exxon Valdez experience. Microbial. Biotech., 2 (2), 213-221 (9 pages).

Bouchez M.; Blanchet D.; Vandecasteele J. P., (1996). The microbiological fate of polycyclic aromatic hydrocarbons: Carbon and oxygen balances for bacterial degradation of model compounds. Appl. Microbiol. Biotech., 45 (4), 556561 (6 pages).

Cerniglia, C. E., (1993). Biodegradation of polycyclic aromatic hydrocarbons. Curr. Opin. Biotech., 3 (2-3), 331-338 (8 pages).

Diaz, M.P.; Grigson, S. J.W.; Peppiatt, C. J.; Grant Burgess, J., (2000). Isolation and characterization of novel hydrocarbondegrading Euryhaline consortia from crude oil and mangrove sediments. Mar. Biotech., 2 (6), $522-532$ (11 pages).

Fagbote, E. O.; Olanipekun, E. O., (2010). Levels of polycyclic aromatic hydrocarbons and polychlorinated biphenyls in sediment of bitumen deposit impacted area. Int. J. Environ. Sci. Tech., 7 (3), 561-570 (10 pages).

Gomes, R. C. B.; Nogueira, R.; Oliveira, J. M.; Peixoto, J.; Brito, A. G., (2006). Kinetics of fluorene biodegradation by a mixed culture. Proceedings of the second IASTED International Conference Advanced Technology in the Environmental Field. 6-8 Feb. ,2006, Lanzarote, Canary Island, Spain. 84-87.

Haghighat S.; Akhavan Sepahy, A.; Mazaheri Assadi, M.; Pasdar, H., (2008). Ability of indigenous Bacillus licheniformis and Bacillus subtilis in microbial enhanced oil recovery. Int. J. Environ. Sci. Tech., 5 (3), 385-390 (6 pages).

Harayama S.; Kasai Y.; Hara A., (2004). Microbial communities in oil-contaminated seawater. Curr. Opin. Biotech., 15 (3), 205-214 (10 pages).

Head, I. M.; Jones, D. M.; Röling, W. F. M., (2006). Marine microorganisms make a meal of oil. Nat. Rev. Microbiol., 4 (3), 173-182 (10 pages).

Hughes, J. B.; Beckles, D. M.; Chandra, S. D.; Ward, C. H., (1997). Utilization of bioremediation processes for the treatment of PAH-contaminated sediments. J. Ind. Microbiol. Biotech., 18 (2-3), 152-160 (9 pages).

Kang, H.; Hwang, S. Y.; Kim, Y. M.; Kim, E.; Kim, Y. S.; Kim, S. K.; Kim, S. W.; Cerniglia, C. E.; Shuttleworth, K. L.; Zylstra, G. J., (2003). Degradation of phenanthrene and naphthalene by a Burkholderia species strain. Can. J. Microbiol., 49 (2), 139-144 (6 pages).

Kim, Y. H.; Freeman, J. P.; Moody, J. D.; Engesser, K. H.; Cerniglia, C. E., (2005). Effects of $\mathrm{pH}$ on the degradation of phenanthrene and pyrene by Mycobacterium vanbaalenii PYR-1. Appl. Microbiol. Biotech., 67 (2), 275-285 (11 pages)

Kiyohara, H.; Nagao, K.; Yana, K., (1982). Rapid screen for bacteria degrading water-insoluble, solid hydrocarbons on agar plates. Appl. Environ. Microbiol., 43 (2), 454-457 (4 pages).

Kumar, M.; Leon, V.; Materano, A. D. S.; Llzins, Olaf, O. A., (2007). A halotolerant and thermotolerant bacillus sp. degrades hydrocarbons and produces tensio-active emulsifying agent. World J. Microbiol. Biotech., 23 (2), 211-220 (10 pages).

Lee, K. H.; Byeon, S. H., (2010). The biological monitoring of urinary 1 hydroxypyrene by $\mathrm{PAH}$ exposure among smokers. Int. J. Environ. Res., 4 (3), 439-442 (4 pages).

Margesin R.; Schinner F., (2001). Potential of halotolerant and halophilic microorganisms for biotechnology. Extremophiles, 5 (2), 73-83 (11 pages).

Mohanan, S., Maruthamuthu, S., Muthukumar, N., Rajasekar, A., Palaniswamy, N., (2007). Biodegradation of Palmarosa oil (Green oil) by Serratia marcescens. Int. J. Environ. Sci. Tech., 4 (2), 277-281 (5 pages).

Moody, J. D.; Freeman, J. P.; Doerge, D. R.; Cerniglia, C. E., (2001). Degradation of phenanthrene and anthracene by cell suspensions of mycobacterium sp. Strain PYR-1. Appl. Environ. Microbiol., 67 (4), 1476-1483 (8 pages).

Nicholson, C. A.; Fathepure, B. Z., (2004). Biodegradation of Benzene by Halophilic and halotolerant bacteria under aerobic conditions. Appl. Microbiol. Biotech., 70 (2), 12221225 (4 pages).

Nwuche, C. O.; Ugoji, E. O., (2008). Effects of heavy metal pollution on the soil microbial activity. Int. J. Environ. Sci. Tech., 5 (3), 409-414 (6 pages).

Okafor, E. Ch., Opuene, K., (2007). Preliminary assessment of trace metals and polycyclic aromatic hydrocarbons in the sediments. Int. J. Environ. Sci. Tech., 4 (2), 233-240 (8 pages).

Osuji, L. C.; Ezebuiro, P. E., (2006). Hydrocarbon contamination of a typical mangrove floor in Niger Delta, Nigeria. Int. J. Environ. Sci. Tech., 3 (3), 313-320 (8 pages).

Penet, S.; Marchal, R.; Sghir, A.; Monot, F., (2004). Biodegradation of hydrocarbon cuts used for diesel oil formulation. Appl. Microbiol. Biotech., 66 (1), 40-47 (8 pages).

Perugini. M.; Visciano, P.; Giammarino, A.; Manera, M.; Nardo, W. D.; Amorena M., (2007). Polycyclic aromatic hydrocarbons in marine organisms from the Adriatic Sea Italy. Chemosphere, 66 (10), 1904-1910 (7 pages).

Pinyakong, O.; Habe, H.; Supaka, N.; Pinpanichkarn, P.; Juntongjin, K.; Yoshida, T.; Furihata, K.; Nojiri, H.; Yamane. H.; Omori, T., (2000). Identification of novel metabolites in the degradation of phenanthrene by Sphingomonas $s p$. strain P2. FEMS Microbiol. Lett., 191 (1), 115-121 (7 pages).

Seo, J. S.; Keum, Y. S.; Hu, Y.; Lee, S. E.; Li, Q. X., (2007). Degradation of phenanthrene by Burkholderia sp. C3: Initial 1,2-and 3,4-dioxygenation and meta-and ortho-cleavage of naphthalene-1,2-diol. Biodegradation., 18 (1), 123-131 (9 pages).

Solano-Serena F.; Marchal R.; Ropars M.; Lebeault J. M.; Vandecasteele J. P., (1999). Biodegradation of gasoline: Kinetics mass balance and fate of individual hydrocarbons. J. Appl. Microbiol., 86 (6), 1008-1016 (9 pages).

Swannell, R. P .J.; Lee, K.; McDonagh, M., (1996). Field evaluations of marine oil spill bioremediation. Microbiol. Rev., 60 (2), 342-365 (24 pages).

Swannell, R. P. J.; Mitchell, D.; Lethbridge, G.; Jones, D.; Heath, D.; Hagley, M.; Jones, D. M.; Petch, S.; Milne, R.; Croxford, R.; Lee, K., (1999). A field demonstration of the efficiency of bioremediation to treat an oiled shoreline following the Sea Empress incident. Environ. Tech., 20 (8), 863-874 (12 pages). 
Tam, N. F. Y.; Guo, C. L.; Yau, W. Y.; Wong, Y. S., (2002). Preliminary study on biodegradation of phenantherene by bacteria isolated from mangrove sediments in hong kong. Marine Poll. Bull., 45 (1-12), 316- 324 (9 pages).

Tehrani, D. M.; Minoui, S.; Herfatmanesh, A., (2009). Effect of salinity on biodegradation of polycyclic aromatic hydrocarbons (PAHs) of heavy crude oil in soil. Bull. Environ. Contam. Toxicol., 82 (2), 179-184 (6 pages). Venosa, A. D.; Suidan, M. T.; Wrenn, B. A.; Strohmeier, K. L.; Haines, J. R.; Eberhardt, B. L.; King, D.; Holder, E., (1996). Bioremediation of an experimental oil spill on the shoreline of Delaware Bay. Environ. Sci. Tech., 30 (5), 1764-1775 (12 pages).
Wang, J.; Xu, H.; An, M.; Yan, G., (2008). Kinetics and characteristics of phenanthrene degradation by a microbial consortium. Petrol. Sci., 5 (1), $73-78$ (6 pages).

Williams, P. A.; Sayers, J. R., (1994). The evolution of pathways for aromatic hydrocarbon oxidation in Pseudomonas. Biodegradation, 5 (3-4), 195-217 (23 pages).

Yu, S. H.; Ke, L.; Wong, Y. S.; Tam N. F. Y., (2005). Degradation of polycyclic aromatic hydrocarbons by a bacterial consortium enriched from mangrove sediments. Environ. Int., 31 (2), 149-154 (6 pages).

Yuan, S. Y.; Wei, S. H.; Chang. B. V., (2000). Biodegradation of polycyclic aromatic hydrocarbons by a mixed culture. Chemosphere, 41 (9), 1463-1468 (6 pages).

\section{AUTHOR (S) BIOSKETCHES}

Arulazhagan, P., Ph.D., Post doctoral researcher, Department of Civil and Environmental Engineering, Sung Kyun Kwan University, 300

Cheon Cheon-Dong, Jangan-Gu, Suwon, Gyeonggi-Do, South Korea. Email: arulazhagan_p@yahoo.co.in

Vasudevan, N., Ph.D., Professor, Centre for Environmental Studies, Anna University, Chennai - 600 025, India.

Email: nvasudevan@annauniv.edu

Yeom, I. T., Ph.D., Professor, Department of Civil and Environmental Engineering, Sung Kyun Kwan University, 300 Cheon Cheon-Dong, Jangan-Gu, Suwon, Gyeonggi-Do, South Korea. Email: yeom@skku.edu

How to cite this article: (Harvard style)

Arulazhagan P.; Vasudevan, N.; Yeom, I. T., (2010). Biodegradation of polycyclic aromatic hydrocarbon by a halotolerant bacterial consortium isolated from marine environment. Int. J. Environ. Sci. Tech., 7 (4), 639-652. 